\title{
Flora das cangas da Serra dos Carajás, Pará, Brasil: Araceae
}

\author{
Flora of the canga of Serra dos Carajás, Pará, Brazil: Araceae
}

Marcus A. Nadruz Coelho ${ }^{1,2}$

\begin{abstract}
Resumo
Este estudo tem como objetivo o inventário das espécies de Araceae registradas para as cangas da Serra dos Carajás, no estado do Pará, apresentando descrição detalhada, ilustração e comentários morfológicos das espécies. São registradas 23 espécies de Araceae para a área de estudo, sendo oito para Philodendron, seis para Anthurium, duas para Dieffenbachia, Monstera e Spathiphyllum e uma para Heteropsis, Syngonium e Wolffia. Palavras-chave: FLONA Carajás, taxonomia, espécies ameaçadas, flora.
\end{abstract}

\begin{abstract}
This study aims to survey the species of Araceae registered for the canga of the Serra dos Carajás, in the state of Pará, with detailed description, illustration and morphologic comments on the species. Twenty three species of Araceae were registered for the study area, eight Philodendron, six Anthurium, two for Dieffenbachia, Monstera and Spathiphyllum and one for Heteropsis, Syngonium and Wolffia.
\end{abstract}

Key words: FLONA Carajás, taxonomy, threatened species, flora.

\begin{abstract}
Araceae
Ervas perenes. Caules aéreos eretos, escandentes ou procumbentes, ou subterrâneos, rizomatosos, cormosos ou tuberosos. Entrenós longos a extremamente curtos, frequentemente com raízes adventícias ao longo destes. Folhas espiraladas ou dísticas, inteiras ou compostas, 3-partidas, palmadas, pedadas ou pinadas, raramente peltadas, vaginantes na base ou ao longo do pecíolo, algumas vezes com genículo. Venação reticulada ou peniparalelinérvea. Inflorescências terminais, pseudolaterais, 1-várias. Pedúnculos longos a reduzidos. Espádice com flores bissexuadas ou unissexuadas, nesse caso com flores pistiladas na base e estaminadas no ápice, às vezes com flores estaminadas estéreis intercaladas. Flores com perigônio evidente, ou tépalas muito reduzidas ou ausentes, hipóginas, actinomorfas, protogínicas. Estames livres ou conados, anteras geralmente extrorsas, conectivo frequentemente hipertrofiado.
\end{abstract}

Ovário sincárpico, 1-47-locular, óvulos 1-vários por lóculo. Frutos bacáceos ou utriculares, isolados ou em sincarpia. Sementes com ou sem endosperma, testa fina e espessada.

A família Araceae divide-se, atualmente, em nove subfamílias e está representada por 125 gêneros e, aproximadamente, 3550 espécies (Boyce \& Croat 2016), com distribuição cosmopolita. No Brasil ocorre em todo o território nacional com 36 gêneros e 488 espécies (Coelho 2014, 2006). No estado do Pará ocorrem 19 gêneros e 102 espécies, e na Serra dos Carajás, oito gêneros e 23 espécies foram encontradas. A família é muito utilizada em ornamentação, cujos principais gêneros cultivados são: Anthurium Schott, Aglaonema Schott, Alocasia (Schott) G. Don, Colocasia Schott, Cryptocoryne Fisch. ex Wydler, Epipremnum Schott, Gonatopus Hook. F. ex Engl., Homalomena Schott, Lasia Lour., Philodendron Schott, Rhaphidophora Hassk., Typhonium Schott, Typhonodorum Schott e Zantedeschia Spreng.

\footnotetext{
Instituto de Pesquisas Jardim Botânico do Rio de Janeiro, R. Pacheco Leão 915, 22460-030, Rio de Janeiro, RJ, Brasil.

${ }^{2}$ Autor para correspondência: mnadruz@jbrj.gov.br
} 


\section{Chave de identificação dos gêneros de Araceae das cangas da Serra dos Carajás}

1. Plantas aquáticas

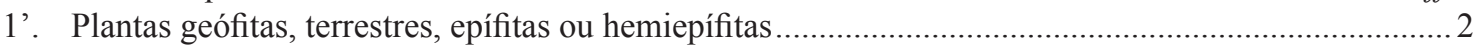

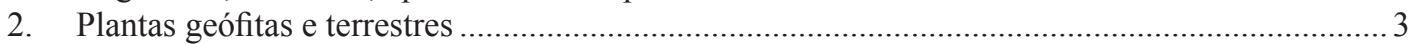

3. Lâmina foliar com nervuras secundárias e terciárias reticuladas, bainha menor do que a metade do comprimento do pecíolo. 1. Anthurium

3'. Lâmina foliar com nervuras paralelo-pinadas, bainha maior do que a metade do comprimento do pecíolo.....

4. Pecíolo sem genículo; pedúnculo menor que o comprimento do pecíolo; espádice com flores unissexuadas

2. Dieffenbachia

4'. Pecíolo com genículo; pedúnculo maior que o comprimento do pecíolo; espádice com flores bissexuadas.

5. Spathiphyllum

2'. Plantas epífitas ou hemiepífitas.

5. Lâmina foliar com nervuras secundarias e terciárias reticuladas; flores com perigônio

1. Anthurium

5'. Lâmina foliar sem nervuras reticuladas; flores sem perigônio.

4. Monstera

6. Lâmina foliar adulta com perfurações.

6'. Lâmina foliar adulta inteira

7. Pecíolo sem genículo; espádice com flores unissexuadas

7. Philodendron

7'. Pecíolo com genículo; espádice com flores bissexuadas 3. Heteropsis

\section{Anthurium Schott}

O gênero Anthurium compreende ervas de caule ereto, trepador e, raramente, rizomatoso; folha com pecíolo geniculado com várias formas em corte transversal, bainha menor do que a metade do comprimento do pecíolo, com lâmina variável na forma, membranácea a coriácea. As inflorescências são sempre solitárias, com pedúnculo geralmente alongado, roliço a anguloso e espata geralmente persistente, linear a ovada, ereta a reflexa. As flores são bissexuadas com 4 tépalas, 4 estames livres com anteras curtas, ovário 2-locular, com 1-2 óvulos por lóculo, e estigma pequeno, levemente capitado. Anthurium possui cerca de 950 espécies, distribuindo-se na América Tropical e ilhas do Caribe. Ocorre nas florestas úmidas tropicais. No Brasil são encontrados aproximadamente 140 táxons, no estado do Pará 14 (BFG 2015) e para a Serra dos Carajás, seis táxons.

\section{Chave de identificação das espécies de Anthurium das cangas da Serra dos Carajás}

1. Lâmina foliar palmaticomposta

2. Margem dos folíolos sinuada

1.5. Anthurium sinuatum

2'. Margem dos folíolos inteira 1.3. Anthurium kunthii

1'. Lâmina foliar inteira

3. Lâmina foliar com nervura coletora; nervuras secundárias $>12$

3'. Lâmina foliar sem nervura coletora; nervuras secundárias $<12$

4. Pedúnculo mais do que três vezes o comprimento do pecíolo. 1.2. Anthurium gracile

4'. Pedúnculo menos do que três vezes o comprimento do pecíolo

5. Nervuras secundárias 5-8 pares; frutos avermelhados ........1.1. Anthurium bonplandii

5. Nervuras secundárias 7-10 pares; frutos arroxeados ......1.4. Anthurium lindmanianum

1.1. Anthurium bonplandii Bunting, Acta Bot. Venez. 10: 267. 1975.

Figs. 1a-c; 2a-c

Epífita a terrestre de caule aéreo reto, seiva leitosa ausente. Catafilos e profilos inteiros a levemente decompostos no ápice e caducos para a base do caule, 2,4-4,6 cm compr., bainha 2,3-2,7 cm compr., pecíolo 3,4-12,7 cm compr., genículo 0,4-1 cm compr., lâmina elíptica, ápice obtuso-reto, base agudo-cuneada, 11,6-34,4 × 3,5-13,3 cm, nervuras secundárias 5-8 pares, reticuladas, nervura 


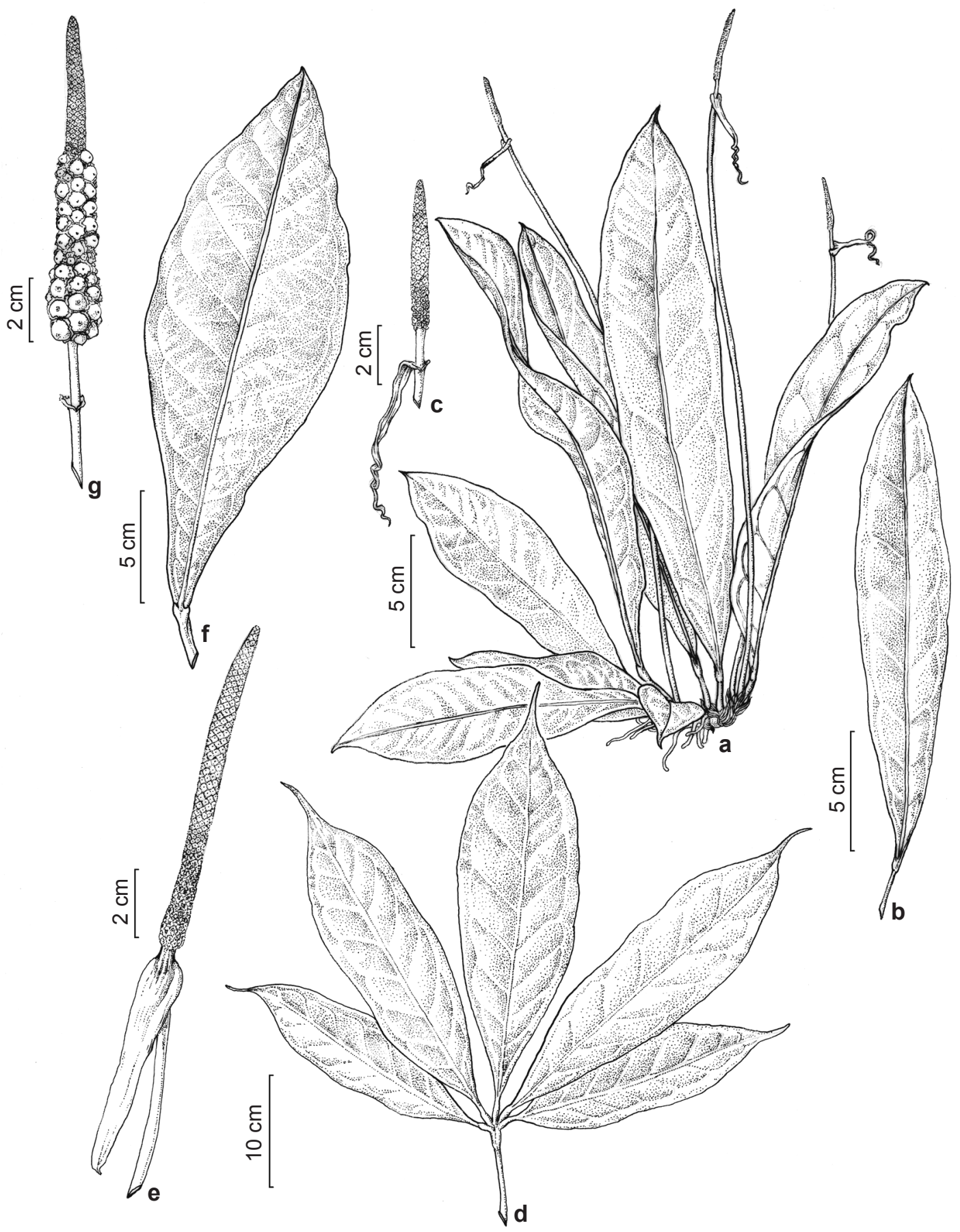

Figura 1 - a-c. Anthurium bonplandii - a. hábito; b. detalhe da folha; c. detalhe da inflorescência. d-e. Anthurium kunthii - d. detalhe da folha; e. detalhe da inflorescência. f-g. Anthurium lindmaniaum - f. detalhe da folha; g. detalhe da inflorescência (a-c. D.C. Daly 1697; d-e. AJ Arruda 731; f-g. N. Rosa 5043).

Figure 1 - a-c. Anthurium bonplandii - a. habit; b. leaf detail; c. inflorescence detail. d-e. Anthurium kunthii - d. leaf detail; e. inflorescence detail. f-g. Anthurium lindmaniaum - f. leaf detail; g. inflorescence detail (a-c. D. C. Daly 1697; d-e. AJ Arruda 731; f-g. N. Rosa 5043). 
basal ausente, nervura coletora ausente. Inflorescência com pedúnculo sem variegação, 30-55,9 cm compr., espata esverdeada com estrias avermelhadas, espádice vináceo, estipitado, 5-10 cm compr., estípite 1,2-3,7 cm compr., flores bissexuadas, perigônio presente. Frutos avermelhados.

Material selecionado: Canaã dos Carajás, Serra SulCorpo A/B, 6²0'46”'S, 50²5'49''O, 724 m, 8.X.2009, fl., V.T. Giorni et al. 341 (BHCB); Floresta Nacional de Carajás, Serra Sul-Corpo D, 6²3'57'S, 50²0'48'O, 771 m, 6.XII.2007, fr., N.F.O. Mota et al. 1080 (BHCB). Parauapebas, Serra dos Carajás, 5.XII.1981, fr., D.C. Daly et al. 1697 (MG);

Anthurium bonplandii é facilmente reconhecida pela lâmina coriácea, ausência de nervuras marginais e frutos avermelhados.

Espécie com distribuição na Guiana, Colômbia e Venezuela (Croat 1991). No Brasil ocorre nos estados Amazonas, Pará, Rondônia e Roraima. Na Serra dos Carajás é registrada para Serra Norte, e Serra Sul: S11A, S11B e S11D. Floresce em outubro e frutifica em dezembro.

1.2. Anthurium gracile (Rudge) Lindl., Edwards's Bot. Reg. 19: t. 1635. 1833.

Epífita de caule aéreo reto, ausência de seiva leitosa. Catafilos e profilos inteiros a levemente decompostos no ápice e caducos para a base do caule, 1-2,9 cm compr., bainha 0,6-2,1 cm compr., pecíolo 2,2-21,2 cm compr., genículo $0,2-0,8 \mathrm{~cm}$ compr., lâmina linear, elíptica, ápice agudo-reto a acuminado, base agudo-cuneada, 11,8-34,9 $\times$ 0,7-8,1 cm, nervuras secundárias 13-19 pares, nervura basal ausente, nervura coletora saindo da base laminar, 0,1-0,5 cm afastada da margem. Inflorescência com pedúnculo avermelhado, sem variegação, 3,6-43,1 cm compr., espata esverdeado-avermelhada, persistente em pósantese, 0,6-3,2 × 0,2, espádice avermelhado, séssil, 0,9-13,6 cm compr., flores bissexuadas, perigônio presente. Frutos avermelhados.

Material selecionado: Canaã dos Carajás, Serra SulCorpo A, 6020'41''S, 2433'13'O, 601 m, 14.II.2010, fr., F.D. Gontijo 58 (BHCB); Serra Sul-corpo C, 6²3'02'S, $50^{\circ} 23$ '43”O, 788 m, 28.VI.2010, fl., T.E. Almeida et al. 2411 (BHCB); Serra Sul-Corpo D, 6²3'22"S, 50²1'08'O, 634 m, 3.X.2009, fl., V.T. Giorni et al. 305 (BHCB). Parauapebas, Igarapé Baia, XI.2012, fl., L.C.B. Lobato \& L. Ferreira 4127 (MG).

Anthurium gracile é facilmente reconhecida pela lâmina alongada, pedúnculo e espádice delgados, e frutos avermelhados.

Espécie com distribuição na Guatemala, Belize, Costa Rica, Panamá, Honduras, Nicarágua,
Guianas e Peru (Croat 1983). No Brasil ocorre nos estados Acre, Amapá, Amazonas, Pará, Roraima, Mato Grosso, Bahia, Paraíba, Pernambuco e Sergipe. Na Serra dos Carajás é registrada para Serra Sul: S11A, S11C e S11D. Floresce em junho, outubro, novembro e frutifica em fevereiro.

1.3. Anthurium kunthii Poepp., Nov. Gen. Sp. Pl., 3: 84. 1845.

Fig. 1d-e

Rupícola de caule ereto, ausência de seiva leitosa. Catafilos e profilos inteiros no ápice e para a base do caule, 4-6 cm compr., bainha não observada, pecíolo $36,9 \mathrm{~cm}$ compr., genículo 0,6 cm compr., lâmina lobada-palmatissecta, folíolos elípticos de margem inteira, sem variegação, ápice agudo-reto a obtuso-acuminado, base agudocuneada, 20,4-29 × 4,7-8,5 cm, 7-10 pares, nervura basal ausente, nervura coletora presente, 0,6-0,7 cm afastada da margem. Inflorescência com pedúnculo sem variegação, $31,1 \mathrm{~cm}$ compr., espata $6,7 \times 1,3 \mathrm{~cm}$, oblonga, espádice $10,1 \mathrm{~cm}$ compr., séssil, flores bissexuadas, perigonio presente. Frutos não observados.

Material selecionado: Canaã dos Carajás, S11B, 6'21'21'S, 50²3'26”W, $700 \mathrm{~m}$ alt., 20.III.2012, fl., A.J. Arruda et al. 731 (MG).

Anthurium kunthii pode ser reconhecida pela lâmina lobada-palmatissecta, catafilos e profilos inteiros no ápice e para a base do caule.

Distribui-se nos estados do Acre, Amazonas, Bahia e Minas Gerais. Na Serra dos Carajás é registrada para a Serra Sul: S11B. Floresce em março.

1.4. Anthurium lindmanianum Engl., Jahrb. Syst. 25: 367.1898. Fig. 1f-g

Terrestre de caule ereto, ausência de seiva leitosa. Catafilos e profilos inteiros e levemente decompostos no ápice do caule, não observados para a base do caule, 2,5-9,4 cm compr., bainha 2,1-4,4 cm compr., pecíolo 4,7-27,1 cm compr., genículo 0,3-1,5 cm compr., lâmina inteira, elíptica a raramente ovada, sem variegação, ápice agudo-reto, base agudo-cuneada a obtusoconvexa, 11,6-52,4 × 3,3-16,6 cm, nervuras secundárias 7-11 pares, nervura basal ausente, nervura coletora ausente. Inflorescência com pedúnculo sem variegação, 39,5-74 cm compr., espata esverdeada, 3,7-6 × 1,2-2 cm, espádice esverdeado, séssil a estipitado, 6-11,65 cm compr., estípite 0,4-5,3 cm compr., flores bissexuadas, perigônio presente. Frutos maduros arroxeados. 
Material selecionado: Canaã dos Carajás, Serra Sul, $\mathrm{S} 11 \mathrm{~B}, 6^{\circ} 21^{\prime} 09^{\prime} \mathrm{S}, 50^{\circ} 23$ '26"O, 729 m, 2.XII.2015, fr., (MG); Serra Sul, S11C, 6²0’46”S, 50²4'54”O, 745 m alt., fl., R.M. Harley et al. 57436 (MG); Serra sul-corpo D, 6²3'57'S, 50²0'48'W, 771 m, 6.XII.2007, fl., N.F.O. Mota et al. 1080 (MG). Parauapebas, Platô N1, Serra Norte, 6¹8'00"S, 50¹6'59”O, 29.XI.2013, fl., R.S. Santos et al. 124 (MG); Platô N4, vegetação de canga, 16.IV.2010, fl., L.C.B. Lobato et al. 3904 (MG); Platô N5, vegetação de canga, 16.III.2015, fl., L.C.B. Lobato 4332 (MG).

Anthurium lindmanianum pode ser reconhecida pela lâmina elíptica, inflorescência com pedúnculo alongado, maior que o comprimento do pecíolo e do espádice.

É endêmica do Brasil, encontrada nos estados do Pará, Rondônia, Tocantins, Mato Grosso, Goiás e Mato Grosso do Sul. Na Serra dos Carajás é registrada na Serra Norte: N1, N4 e N5, e na Serra Sul, S11B, S11C, S11D. Floresce em março, abril, novembro e dezembro, Frutifica em dezembro

1.5. Anthurium sinuatum Benth. ex Schott, Oest. Bot. Woch. 7: 318.1857.

Rupícola a epífita de caule aéreo reto, ausência de seiva leitosa. Catafilos e profilos inteiros e persistentes no ápice e para a base do caule, 3,8-8,6 cm compr., bainha 2-7,9 cm compr., pecíolo 54,5-88,8 cm compr., genículo 0,4-1,3 cm compr., lâmina palmatissecta, folíolo membranáceo em material seco, de margem sinuada, sem variegação, obovada a elíptica, ápice agudo-acuminado, base agudo-cuneada, 23,9-42,7 × 5,2-10,1 cm, nervuras secundárias 7-9 pares, nervura basal ausente, nervura coletora saindo da base laminar, $0,4-1 \mathrm{~cm}$ afastada da margem. Inflorescência com pedúnculo sem variegação, 28-46,2 cm compr., espata esverdeada, persistente em pós-antese, 9,5-16,3 $\times 1,1-1,7$, espádice séssil, $5-17,4 \mathrm{~cm}$ compr., flores bissexuadas, perigônio presente. Frutos não observados.

Material selecionado: Canaã dos Carajás, Serra SulCorpo A/B, 6 $20^{\prime} 31^{\prime \prime} \mathrm{S}, 50^{\circ} 24^{\prime} 31^{\prime \prime} \mathrm{O}, 650 \mathrm{~m}, 4 . \mathrm{X} .2009$, fl., V.T. Giorni et al. 331 (BHCB); Serra Sul-Corpo B, 6020'41"S, 50'24'33"O, 616 m, 14.II.2010, fl., T.E. Almeida et al. 2168 (BHCB); S11-C, 6024'07'S, $50^{\circ} 23^{\prime} 10^{\prime}$ 'O, $664 \mathrm{~m}$, 29.I.2012, fl., L.V.C. Silva et al. 1165 (BHCB). Paraupebas, N3, Mata Baixa, 602'31's, 50¹3'09”'O, 606 m, 22.VI.2012, fl., L.V.C. Silva et al. 1284 (BHCB).

Anthurium sinuatum, na área de estudo, é facilmente reconhecida pela lâmina palmatissecta com 7 folíolos e pedúnculo alongado.

Distribui-se amplamente na América do Sul (Madison 1978). No Brasil é encontrada nos estados Amapá, Amazonas, Bahia, Ceará, Goiás, Minas
Gerais, São Paulo e Paraná. Na Serra dos Carajás é registrada na Serra Norte: N3, e Serra Sul: S11A, $\mathrm{S} 11 \mathrm{~B}$ e S11C. Floresce em janeiro, fevereiro, junho e outubro. Frutificação não observada.

\subsection{Anthurium sp.1}

Rupícola, caule aéreo, ausência de seiva leitosa; catafilos e profilos retos, inteiros no ápice e decompostos em fibras para a base do caule, 1,5-4,7 cm compr., bainha 1,5-2 cm compr., pecíolo 5-12 cm compr., genículo $0,4-0,7 \mathrm{~cm}$ compr., lâmina foliar elíptica, ápice agudo-acuminado a convexoacuminado, base agudo-cuneada a obtuso-convexo, 17,6-24 × 4,8-7,3 cm, nervuras secundárias 8-11, nervura basal ausente, nervura coletora ausente; inflorescência com pedúnculo sem variegação, 29,8-51,5 cm compr., espata amarelo-esverdeada a esverdeada, espádice acastanhado-acinzentado a acastanhado, 2,4-5,3 cm compr., estipitado 1,7-3,8 cm compr., flores bissexuadas, perigônio presente. Frutos não observados.

Material selecionado: Ourilândia, vegetação de canga, 6030'33"S, 5109'23”O, $633 \mathrm{~m}$ alt., 3.V.2016, fl., P.L. Viana et al. 6211 (MG); Parauapebas, Serra de Carajás, N7, 6 ${ }^{\circ} 10^{\prime} 02^{\prime \prime}$ S, 5009'33"O, 716 m alt., 24.II.2016, fl., R.M. Harley et al. 57387 (MG).

É reconhecida pelo número de nervuras laterais (8-11), pecíolo $1 / 4$ a 1/5 do tamanho do pedúnculo e presença de estípite. Muito semelhante a $A$. lindmanianum que apresenta pedúnculo $<3$ vezes o tamanho do pecíolo e espádice $>6 \mathrm{~cm}$ compr., enquanto Anthurium sp. 1 apresenta pedúnculo $>3$ vezes o tamanho do pecíolo e espádice $<6 \mathrm{~cm}$ compr.

Espécie com distribuição conhecida, até o momento, no estado do Pará, Serra dos Carajás, na Serra Norte: N7, e na Serra Arqueada, município de Ourilândia do Norte. Floresce em fevereiro e maio. Frutificação não observada.

\section{Dieffenbachia Schott}

O gênero Dieffenbachia caracteriza-se por apresentar hábito terrestre, pecíolo e lâmina foliar distintas, flores unisexuadas sem perigônio distribuídas no espádice em zonas masculinas e femininas, esta última adnata à espata, e estames em sinandrios. Oferece uma grande variedade de cores nas folhas, muito utilizadas em paisagismo. Ocorre em florestas úmidas tropicais nas bordas de riachos ou no solo sobre folhas (Mayo et al. 1997). Possui 57 espécies, distribuídas na América do Sul, com centro de diversidade na Colômbia (Boyce \& Croat 2011). No Brasil são encontradas 22 espécies, sendo nove endêmicas do território brasileiro, principalmente nas regiões norte centro-oeste (BFG 2015). 


\section{Chave de identificação das espécies de Diffenbachia das cangas da Serra dos Carajás}

1. Pecíolo foliar $<21 \mathrm{~cm}$ compr., lâmina não variegada, $<10 \mathrm{~cm}$ larg.; frutos esverdeados

1'. Pecíolo foliar $>21 \mathrm{~cm}$ compr., lâmina variegada, $>10 \mathrm{~cm}$ larg.; frutos alaranjados

2.1 Dieffenbachia parvifolia 2.2 Dieffenbachia cf. seguine

2.1. Dieffenbachia parvifolia Engl., Pflanzenr. IV, 23Dc: 591915.

Terrestre de caule aéreo ereto, ausência de seiva leitosa. Catafilos e profilos não observados, bainha $12 \mathrm{~cm}$ compr., pecíolo 19,5-20,8 cm., genículo ausente, lâmina foliar não peltada, membranácea em material seco, não variegada, ovada, ápice agudo-reto, base obtusa a arredondada, ausência de perfurações, $21,7-24,6 \times 7,2-7,8 \mathrm{~cm}$, nervuras secundárias 10 , nervuras basais e coletoras ausentes. Inflorescência com pedúnculo 8,6-10,1 $\mathrm{cm}$ compr., espata persistente na frutificação, espádice com flores unissexuadas, perigônio ausente. Frutos esverdeados.

Material selecionado: Parauapebas, Igarapé Bahia, área do POND, VI.2013, fl. e fr., L.C.B. Lobato \& $L$. Ferreira 4166 (MG).

É reconhecida pela forma ovalada da lâmina foliar e sem variegação.

Espécie endêmica do Brasil, nos estados do Acre, Amazônia e Pará. Na área do projeto, possui somente um único registro para a área de floresta no Igarapé Bahia. Floresce e frutifica no mês de junho.

2.2. Dieffenbachia cf. seguine (Jacq.) Schott, Melet. Bot. 20. 1832.

Terrestre de caule aéreo ereto, ausência de seiva leitosa. Catafilos e profilos $3,1 \mathrm{~cm}$ compr., bainha 4-13,5 cm compr., pecíolo $22-22,7 \mathrm{~cm}$ compr., genículo ausente, lâmina foliar não peltada, membranácea em material seco, variegada, forma não observada, ápice não observado, base obtusa a arredondada, ausência de perfurações, 13,2 $\mathrm{cm}$ larg., nervuras secundárias não observadas, nervuras basais e coletora ausentes. Inflorescência com pedúnculo variegado, $16,7 \mathrm{~cm}$ compr., espata persistente na frutificação, espádice não observados, flores unissexuadas, perigônio ausente. Frutos alaranjados.

Material selecionado: Canaã dos Carajás, Serra Sul, Corpo D, 6024'30'S, 50²3'17'O, 517 m, 3.VII.2010, fr., T.E.Almeida et al. 2476 (BHCB).

Espécie reconhecida pelas folhas esverdeadas com máculas e os frutos alaranjados.

Espécie distribuída por Cuba, Jamaica, Porto Rico, Trinidad, Venezuela, Guiana, Suriname,
Guiana Francesa, Equador, Colômbia e Bolívia (Croat 2004). No Brasil tem ocorrência nos estados Amapá, Amazonas, Pará, Rondônia, Maranhão, Ceará, Pernambuco e Mato Grosso do Sul, porém com registros conhecidos em outras localidades, mas como invasor. $\mathrm{Na}$ área do projeto só é conhecida para Serra Sul: S11D. Frutifica no mês de julho. Floração não observada.

\section{Heteropsis Kunth}

O gênero Heteropsis é dificilmente confundido com outros da família Araceae, pelo típico hábito trepador, pecíolo gerlamente muito curto, sem a bainha bem desenvolida, como na maioria dos outros gêneros. Oferece uma grande variedade na forma do botão axilar, na forma, tamanho e cor da espata, e na coloração dos frutos. Hemiepífitas, ocorrendo nos trópicos em florestas úmidas e terra firme (Soares et al. 2013). O gênero possui 17 espécies, distribuídas nas Américas Centrale Sul, com centro de diversidade na Amazônia (Boyce \& Croat 2011; Soares et al. 2013). No Brasil são encontradas 14 espécies na maioria das regiões brasileiras, sendo uma endêmica do território brasileiro, na região costeira entre o RS e BA (BFG 2015).

3.1. Heteropsis oblongifolia Kunth, Enum. Pl. 3: 60. 1841.

Hemiepífita de caule aéreo herbáceo, ausência de seiva leitosa. Catafilos e profilos não observados, bainha inconspícua, pecíolo sinuado em direção ao ápice, 0,19-0,8 cm compr., genículo 0,19-0,4 cm compr., lâmina foliar não peltada, membranácea em material seco, elíptica a raramente obovada, ápice agudo-acuminado a obtuso-acuminado, base agudo-cuneada, ausência de perfurações, 6,7-15,6 $\times 1,9-5,9 \mathrm{~cm}$, nervuras secundárias várias, nervuras basais ausentes, nervura coletora $0,05-0,18 \mathrm{~cm}$ afastada da margem. Inflorescência com pedúnculo $0,1-0,5 \mathrm{~cm}$ compr., espata esverdeada, caduca na antese, espádice amarelado de flores bissexuadas, 1,4-2,1 cm compr., sem perigônio. Infrutescência $3,9 \mathrm{~cm}$ compr., frutos amarelados.

Material selecionado: Canaã dos Carajás, Serra Sul, Corpo D, 6²4'45”'S, 50²2'39'O, 744 m, 2.VI.2010, fl., 

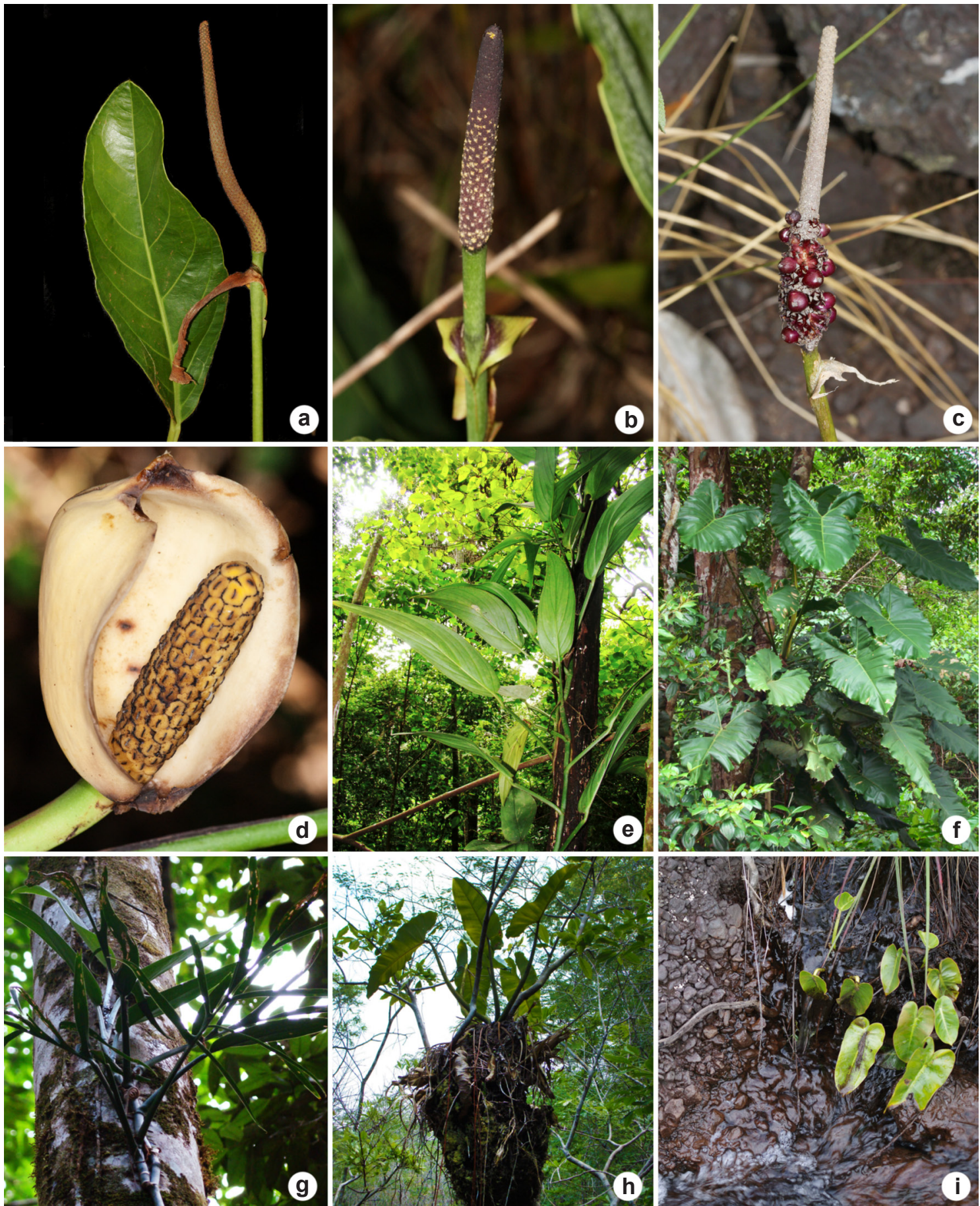

Figura 2 - a-c. Anthurium bonplandii - a. detalhe da folha e da inflorescência; b. detalhe da inflorescência mostrando o estípite; c. detalhe da infrutescência. d. Monstera praetermissa-detalhe da inflorescência. e. Philodendron carajasense - hábito. f. Philodendron solimoesense - hábito. g. Philodendron distantilobum - hábito. h-i. Philodendron sp. 1 -h. hábito epifítico; i. hábito rupícola.

Figure 2 - a-c. Anthurium bonplandii - a. detail of leaf and inflorescence; b. detail of the inflorescence showing the stipe; c. infructescence detail. d. Monstera praetermissa - inflorescence detail. e. Philodendron carajasense - habit. f. Philodendron solimoesense - habit. g. Philodendron distantilobum - habit. h-i. Philodendron sp. 1 - h. epiphytic habit; i. rupicolous habit. 
L.L. Giacomin et al. 1185 (BHCB). Parauapebas, N1, 6'2'56"S, 50¹6'1"O, 700 m, 21.VI.2012, fl., L.V.C. Silva et al. 1266 (BHCB); Igarapé baia, XI.2012, fl., L.C.B. Lobato \& L. Ferreira 4113 (MG); Serra Norte, N3, Projeto Carajás, 14.VII.1986, fl., R.B. Torres \& J.W.B. Machado 18438 (UEC).

Facilmente reconhecida pelo hábito hemiepifitico, pecíolos muito curtos com margem sinuada, espádice até $2 \mathrm{~cm}$ compr. e bagas amareladas.

Espécie com distribuição na Bolívia, Colômbia, Costa Rica, Equador, Nicarágua, Peru e Venezuela, entre 50 e $2000 \mathrm{~m}$ altitude. No Brasil ocorre em Floresta Ombrófila Densa, florestas secundárias ou em áreas perturbadas, nos estados Acre, Amapá, Amazonas, Bahia, Espírito Santo, Maranhão, Mato Grosso, Minas Gerais, Pará, Paraná, Pernambuco, Rio de Janeiro e Roraima.
$\mathrm{Na}$ área do projeto é encontrada na Serra Norte: N1, N3, e Serra Sul: S11D. Floresce em junho, julho e novembro. Frutificação não observada.

\section{Monstera Adans.}

Monstera caracteriza-se pelo hábito hemiepifítico, com caule trepador, bainha de comprimento maior do que a metade do pecíolo, lâmina foliar frequentemente perfurada, as vezes profundamente pinatifida, espádice de flores bissexuadas e perigônio ausente. Ocorre típicamente em florestas úmidas, com 38 espécies no mundo, distribuído pela América Tropical e Índias Ocidentais (Mayo et al. 1997). No Brasil são nove espécies, com distribuição ampla em todas as regiões, sendo uma endêmica, e no estado do Pará sete espécies (BFG 2015).

\section{Chave de identificação das espécies de Monstera das cangas da Serra dos Carajás}

1. Lâmina foliar regularmente pinatifida 4.2 Monstera subpinnata

1'. Lâmina foliar com margem inteira ou com poucas lacerações, mas não regularmente pinatifida 4.1 Monstera praetermissa

4.1. Monstera praetermissa E.G. Gonç. \&Temponi, Brittonia, 56: 72, 2004. Fig. 2d

Hemiepífita de caule aéreo herbáceo, sem a presença de seiva. Folhas com bainha 11,2-18,5 cm compr., pecíolo 12,3-19 cm compr., genículo $0,7-1,5 \mathrm{~cm}$ compr., lâmina foliar membranácea em material seco, não peltada, ovada, base obtusa, côncavo-convexa, ápice agudo-acuminado, margem inteira ou com poucas lacerações, mas não regularmente pinatifida, $21,8-33,8 \times 17,2-17,5$ $\mathrm{cm}$., nervuras secundárias 5 pares, ausência de nervura coletora. Inflorescência com pedúnculo $8,5-10,8 \mathrm{~cm}$ compr., espata caduca em antese e frutificação, $5,1 \mathrm{~cm}$ compr., espádice de flores bissexuadas, sem perigônio, 2,8-5,2 cm compr. Frutos não observados.

Material selecionado: Canaã dos Carajás, 6²6'13"S, $50^{\circ} 19^{\prime} 33^{\prime \prime} \mathrm{O}, 337$ m, 01.V.2010, fr., F.D. Gontijo et al. 158 (BHCB). Parauapebas, N3, 602'36"'S, 50¹3'12”O, 593 m, 22.VI.2012, fr., L.V.C. Silva et al. 1281 (BHCB).

Caracteriza-se por apresentar bainha maior que a metade do pecíolo, lâmina foliar com perfurações e bagas amareladas quando maduras.

Espécie de poucos indivíduos conhecidos, mas de ampla distribuição, endêmica do Brasil, ocorrendo nos estados Acre, Pará, Rondônia, Mato Grosso, Bahia, Ceará, Pernambuco, Goiás, Espírito Santo, Minas Gerais, Rio de Janeiro, São Paulo e
Paraná. Na área do projeto é encontrada na Serra Norte: N3, e Serra Sul, em floresta. Frutifica em maio e junho. Floração não observada.

4.2. Monstera subpinnata (Schott) Engl., D.C. Monog. Phan. 2: 267. 1879.

Erva hemiepífita de caule aéreo, ausência de seiva. Folhas com bainha $33,9 \mathrm{~cm}$ compr., pecíolo $36,2 \mathrm{~cm}$ compr, genículo ausente, lâmina foliar membranácea em material seco, não peltada, margem pinatifida sem perfurações, sete pinas por lado e uma terminal, pina linear, base truncada, ápice agudo-reto, $43,4 \times 41,9 \mathrm{~cm}$, nervuras secundárias 15 , ausência de nervuras coletora. Infrutescência com pedúnculo não observado, espata caduca em antese e frutificação, espádice de flores bissexuadas, sem perigônio, 13,5 cm compr. Frutos não observados.

Material selecionado: Parauapebas, Serra dos Carajás $5^{\circ} 49^{\prime} \mathrm{S}, 50^{\circ} 32^{\prime} \mathrm{O}, 225-250 \mathrm{~m}, 01 . \mathrm{VI} .1982$, fr., C.R. Sperling et al. $6196(\mathrm{MG})$.

Caracteriza-se pela lâmina foliar de margem pinatifda e base truncada.

Espécie com distribuição no Equador, Peru, Bolívia e Brasil, onde possui poucas coletas, com distribuição nos estados Acre, Mato Grosso e Pará. $\mathrm{Na}$ área do projeto, foi coletada em uma única localidade, em floresta, provavelmente na região da mina do Salobo. Frutifica em junho. 

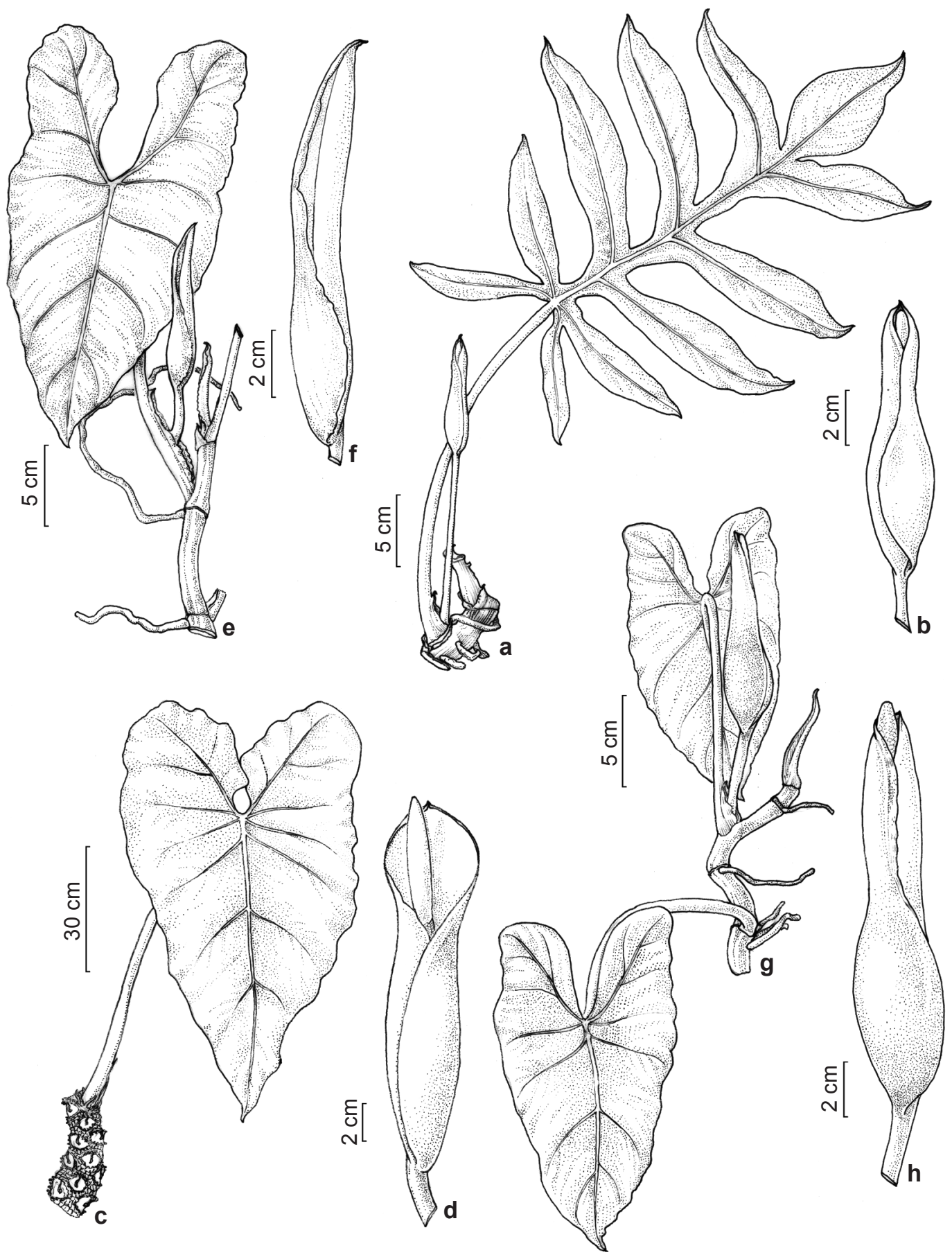

Figura 3 - a-b. Philodendron distantilobum - a. hábito; b. detalhe da inflorescência. c-d. Philodendron solimoesense - c. hábito; d. detalhe da inflorescência. e-h. Philodendron wullschlaegelii-e, g. hábito; f, h. detalhe da inflorescência (a-b. C.R. Sperling 6002; c-d. A. Cardoso 1959; e-f. A.S.L. Silva 1799; g-h. L.M.M. Carreira 3391).

Figure 3 - a-b. Philodendron distantilobum - a. habit; b. inflorescence detail. c-d. Philodendron solimoesense - c. habit; d. inflorescence detail. e-h. Philodendron wullschlaegelii - e, g. habit; f, h. inflorescence detail (a-b. C.R. Sperling 6002; c-d. A. Cardoso 1959; e-f. A.S.L. Silva 1799; g-h. L.M.M. Carreira 3391). 


\section{Philodendron Schott}

O gênero Philodendron caracteriza-se pelo hábito hemiepifítico, raramente rupícola, litófitas, helófitas ou terrestre. Inclui ervas, mas algumas espécies podem se apresentar como arborescentes. Possui inflorescência dividida em zonas feminina (basal), estéril (mediana) e masculina (medianaapical), as vezes com uma quarta zona estéril no ápice. $\mathrm{O}$ gênero possui 490 espécies e distribui-se nas Américas Tropical e Subtropical, no Brasil são conhecidas 168, com 79 endêmicas, e 38 espécies no Pará (BFG 2015).

\section{Chave de identificação das espécies de Philodendron das cangas da Serra dos Carajás}

1. Folha com bainha peciolar quase do tamanho do pecíolo 5.1. Philodendron carajajense

1'. Folha com bainha peciolar menor do que a metade do pecíolo

2. Espécie arborescente com escamas intravaginais visíveis, zona estaminodial mediana do mesmo comprimento ou mais longo do que a zona masculina fértil...... 5.5. Philodendron solimoensense

2'. Espécies não arborescentes com escamas intravaginais inconspícuas, zona estaminodial mediana mais curta do que a zona masculina fértil

3. Margem da lâmina foliar lobada

4. Nervuras secundárias 9 , pedúnculo $3,6-4,8 \mathrm{~cm}$ compr....... 5.4. Philodendron pedatum

4'. Nervuras secundárias 4-5, pedúnculo 6,2-12,1 cm compr.

5.2. Philodendron distantilobum

3'. Margem da lâmina foliar inteira

5. Catafilos e profilos formando massa fibrosa amarronzada, espata completamente avermelhada externamente 5.3. Philodendron fragrantissimum

5'. Catafilos e profilos não formando massa fibrosa amarronzada, espata não completamente avermelhada externamente.

6. Inflorescência 2-6

5.8. Philodendron sp. 2

6'. Inflorescência 1-2

7. Pecíolo intumescido, nervuras secundárias $>5 ; 1$ óvulo por lóculo

5.7. Philodendron sp. 1

7’. Pecíolo não intumescido, nervuras secundárias $<5 ; 5-7$ óvulos por lóculo... 5.6. Philodendron wullschlaegelii

5.1. Philodendron carajasense E.G. Gonç. \& A.J. Arruda, Nordic Journal of Botany 32: 536-539. 2014.

Fig. 2e

Rupícola, hemiepífita de caule aéreo, herbácea, ausência de seiva leitosa. Catafilos e profilos não observados, bainha 2,1-15 cm compr., fechada, pecíolo 2,4-16,2 cm compr., genículo ausente, lâmina foliar não peltada, não lobada, membranácea em material seco, elíptica, inteira, ápice acuminado, agudo-reto a obtuso-convexo, base agudo-cuneada, obtuso-convexa a obtuso-arredondada, ausência de perfurações, 7,8-29,4 × 1,7-11,5 cm, nervuras secundárias 8-12 pares, nervuras basais ausentes, nervura coletora ausente. Inflorescência com pedúnculo 0,9-2,8 cm compr., espata esverdeada externamente, não constrita na região mediana, lâmina persistente pós-antese, $3,8-8,7 \mathrm{~cm}$ compr., espádice 5,1-5,9 cm compr. Frutos não observados. Material selecionado: Canaã dos Carajás, S11-A, 6 20'35'S, 50²4'32”'O, 607 m, 9.XI.2012, fr., I.M.C. Rodrigues et al.
532 (BHCB); Corpo-D, 6²3'29”S, 50¹9'04'O, 594 m, 31.VIII.2010, fl., T.E. Almeida et al. 2510 (BHCB); Cachoeira do André, 6024'37'S, 50¹4'50"O, 12.XII.2012, fl., I.M.C. Rodrigues et al. 601 (BHCB); Serra da Bocaina, 6 ${ }^{\circ} 18^{\prime} 35^{\prime \prime}$ 'S, 50²7'16”O, 696 m, 12.XII.2012, A.J. Arruda et al. 1306 (BHCB). Parauapebas, N1, 6 02 '25”S, 50²6’01”O, 628 m, 8.II.2012, fl., L.V.C. Silva et al. 1201 (BHCB); Serra Norte-N4, 606'31'S, 50¹147'O, 630 m, 29.I.2013, A.J. Arruda et al. 1446 (BHCB); N7, 6009'11'S, 50¹0'45"O, 615 m, 24.VI.2012, fl., L.V.C. Silva et al. 1317 (BHCB).

Philodendron carajasense pode ser reconhecida pela bainha foliar fechada e quase do mesmo tamanho do pecíolo e número de nervuras secundárias de 8-11 pares.

Espécie endêmica da Serra dos Carajás, estado do Pará, onde foi registrada na Serra Sul: S11A,S11D e Serra da Bocaina; e Serra Norte: N1, N4 e N7. Ocorre em áreas de drenagem sobre afloramento ferruginoso associadas a florestas de encosta. Floresce em fevereiro, agosto, dezembro e frutifica em novembro 
5.2. Philodendron distantilobum $\mathrm{K}$. Krause, Pflanzenr. IV, 23Db: 115. 1913. Figs. 2g; 3a-b Hemiepífita de caule aéreo, herbácea, ausência de seiva leitosa. Catafilo retorcido, bainha 2,5-5,7 cm compr., pecíolo $11,3-44,4$ $\mathrm{cm}$ compr., genículo ausente, lâmina foliar não peltada, membranácea em material seco, elíptica, pinatipartida, ápice agudo-reto, base sagitada, ausência de perfurações, $23,2-45,7 \times 18-50,6$ $\mathrm{cm}$, nervuras secundárias $4-5$ pares, nervura basal $0-1$, nervura coletora ausente. Inflorescência com pedúnculo 6,2-12,1 cm compr., espata com tubo esverdeado e lâmina amarelada externamente, constrita na região mediana, lâmina persistente pós-antese, 6,9-9,3 cm compr., espádice 8,4-10,4 $\mathrm{cm}$ compr. Frutos não observados.

Material selecionado: Parauapebas, Serra Norte, N1, 602'27'S, 50¹7'40'O, 533 m, 24.VII.2012, fl., A.J. Arruda et al. 1240 (BHCB); N3, 602'36"S, 50¹3'12”O, 593 m, 22.VI.2012, fl., L.V.C. Silva et al. 1282 (BHCB); Área do POND, 25.XI.2013, fl., L.C.B. Lobato \& L. Ferreira 4259 (MG).

Philodendron distantilobum pode ser reconhecido pela lâmina foliar pinatipartida, com lobos largos e bem separados entre si.

Tem distribuição no Peru e Brasil nos estados do Acre, Amazonas, Pará, Rondônia, Mato Grosso e Goiás. Pelas suas folhas pinatipartidas e pedúnculo maior que a inflorescência, pode ser reconhecida facilmente. Na Serra dos Carajás, foi encontrada na Serra Norte: N1 e N3. Floresce em junho, julho e novembro.

5.3. Philodendron fragrantissimum (Hook.) G. Don, Hort. Brit. Rd.: 3: 632. 1839.

Erva hemiepífita de caule aéreo, ausência de seiva leitosa. Catafilo decompostos formando massa fibrosa amarronzada no ápice do caule, pecíolo 12-20,9 cm compr., genículo ausente, lâmina foliar não peltada, membranácea em material seco, ovada, não lobada, ápice agudo-reto, base côncavo-convexa, ausência de perfurações, 24,3-31,2 × 16,4-20,7cm, nervuras secundárias 5 , nervura basal 1 , nervura coletora ausente. Inflorescência com pedúnculo 2,7-8,2 cm compr., espata avermelhada externamente, lâmina caduca pós-antese, espádice 8-9,1 com compr. Frutos avermelhados.

Material selecionado: Serra dos Carajás, Azul, 5059'S, 50²8’O, 12.VIII.1981, fl., D.C. Daly et al. 1856 (MG); Estrada para Itacaiúnas, 1.II.1985, fr., O.C. Nascimento \& R.P. Bahia $1114(\mathrm{MG})$.

Philodendron fragrantissimum é reconhecida pela forma ovada com base côncavo-convexa da lâmina foliar e frutos avermelhados, 5 pares de nervuras secundárias e espata constrita, pode ser reconhecida facilmente.

Tem distribuição de Belize ao Panamá, Cuba, Trinidad, Colômbia, Peru, Guianas, Venezuela e Brasil, nos estados de Rondônia, Acre, Amazonas, Roraima, Pará, Amapá, Pernambuco, Alagoas, Sergipe, Bahia e Espírito Santo. Na Serra dos Carajás é encontrada em áreas de floresta, como no acampamento Azul e nas proximidades da estrada para Itacaiúnas. Floresce em agosto e frutifica em fevereiro.

5.4. Philodendron pedatum (Hook.) Kunth, Enum. Pl. 3: 49. 1841.

Hemiepífita de caule aéreo, herbácea, ausência de seiva leitosa. Catafilo não observado, pecíolo 41,4 cm compr., genículo ausente, lâmina foliar não peltada, membranácea em material seco, ovada, pinatipartida, ápice agudo-reto, base lobado-sagitada, ausência de perfurações, $41,3 \times 28,9 \mathrm{~cm}$, nervuras secundárias 9 , nervura basal 1 , nervura coletora ausente. Inflorescência com pedúnculo $3,6-4,8 \mathrm{~cm}$ compr., espata esverdeada externamente, não constrita na região mediana, lâmina persistente pós-antese, , 8,7-9 cm compr., espádice 7,7-10,4 cm compr.. Frutos não observados.

Material selecionado: Canaã dos Carajás, Área da Pilha, 6027'30"S, 50¹9'33”O, 8.XII.2012, fl., I.M.C. Rodrigues et al. 564 (BHCB).

Philodendron pedatum pode ser reconhecida pelas suas folhas pinatipartidas de base lobadosagitada e espata não constrita, pode ser reconhecida facilmente.

Tem distribuição no sul da Colômbia, oeste do Equador, norte da Bolívia, Suriname, Guiana Francesa, sul da Venezuela e Brasil na região Norte e nos estados do Mato Grosso, Alagoas, Bahia, Ceará, Pernambuco, Espírito Santo, Minas Gerais e Rio de Janeiro. Na Serra dos Carajás, foi coletada em área de floresta, em Canaã dos Carajás. Floresce em dezembro. Frutificação não observada.

5.5. Philodendron solimoesense A.C. Smith, J. Arnold Arbor. 20: 289. $1939 . \quad$ Figs. 2f; 3c-d

Hemiepífita de caule aéreo, arborescente, ausência de seiva leitosa. Catafilo não observado, pecíolo 83,7 cm compr., genículo ausente, lâmina foliar não peltada, cartácea em material seco, ovada, ápice agudo-reto, base reflexo-cordada, ausência de perfurações, $72,3 \times 37-57,6 \mathrm{~cm}$, nervuras secundárias $4-5$ em ambas as faces, 


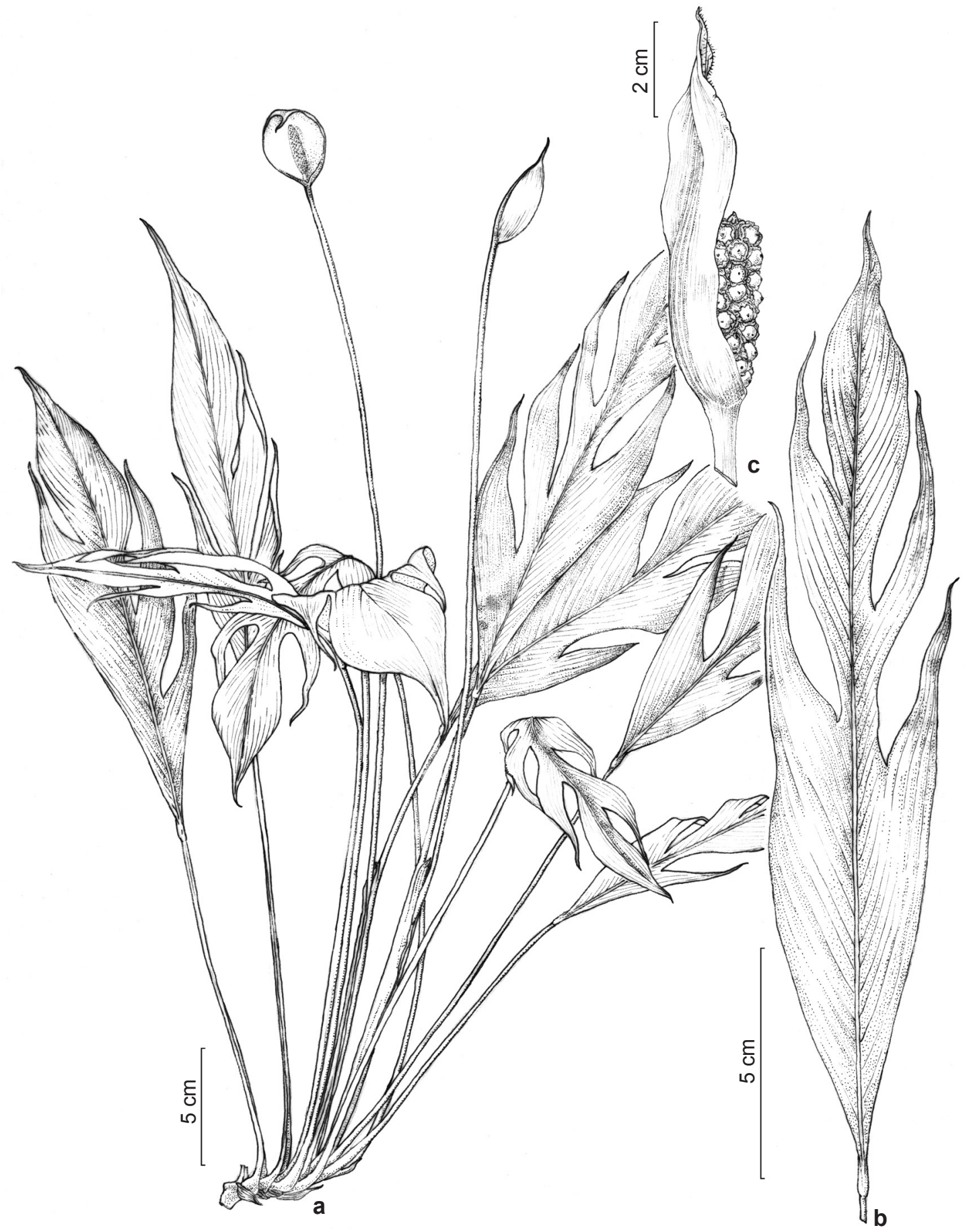

Figura 4 - a-c. Spathiphyllum gardneri - a. hábito; b. detalhe da folha; c. detalhe da inflorescência. (a-c. Silva 1116) Figure 4 - a-c. Spathiphyllum gardneri - a. habit; b. leaf detail; c. inflorescence detail. (a-c. Silva 1116) 
nervura basal 1, nervuras acroscópicas 2-3, nervuras basioscópicas 1-4, nervura coletora ausente. Inflorescência 1 , com pedúnculo $8,5 \mathrm{~cm}$ compr., espata esverdeada externamente, não constrita na região mediana, lâmina persistente pós-antese, 22,2 cm compr., espádice 20-22,5 cm compr. Frutos não observados.

Material selecionado: Parauapebas, Serra Norte, N8, 609'46"S 5009'50"W, 695 m alt., 27.III.2015, fr., $A$. Cardoso et al. 1959 (MG); Serra dos Carajás, 600'S, $50^{\circ} 18^{\prime} \mathrm{W}, 700 \mathrm{~m}, 26 . \mathrm{V} .1969$, est., P. Cavalcante 2181 (MG).

Philodendron solimoesense pode ser reconhecida pelo porte arborescente, lâmina foliar ovada de base cordada, acima de $70 \mathrm{~cm}$ compr.

Espécie com distribuição no hemisfério Norte da América do Sul e no Brasil com ocorrência nos estados de Rondônia, Acre, Amazonas, Pará Amapá, Maranhão e Mato Grosso. Na Serra dos Carajás, foi registrada na Serra Norte: N8 e, provavelmente, N1. Frutifica em março. Floração não observada.

5.6. Philodendron wullschlaegelii Schott, Syn. Aroid. 94.1856.

Fig. $3 \mathrm{e}-\mathrm{h}$

Erva, rupícola a hemiepífitade caule aéreo, ausência de seiva leitosa. Catafilo reto, $5,9 \mathrm{~cm}$ compr., pecíolo 9,1-49,6 cm compr., genículo ausente, lâmina foliar não peltada, membranácea a cartácea em material seco em material seco, ovada, não lobada, ápice agudo-reto a obtuso-convexo, base reflexo-cordada, ausência de perfurações, 8,4-52,8 × 4,6-32,2 cm, nervuras secundárias 3-4, nervura basal 1, nervuras acroscópicas 2-3, nervura basioscopica $1-2$, nervura coletora ausente. Inflorescência 1-2, com pedúnculo 4,1-15,2 cm compr., espata esverdeada externamente, não constrita na região mediana, lâmina persistente pósantese, 7,1-13,5 cm compr., espádice com ovário 5-7 óvulos por lóculo. Frutos não observados.

Material selecionado: Canaã dos Carajás, subida da cachoeira, 6²4'28.8'S, 50¹4'54.1'O, 27.IV.2010, fl., F.D. Gontijo et al. 156 (BHCB); Serra Sul, 6²3'58'S, 50²2'31'O, 16.IV.2015, fl., L.M.M. Carreira et al. 3391 (MG); Serra Sul-Corpo D, 6²3'1'S, 50²3'10'O, 700 m, 16.III.2010, fl., V.T. Giorni et al. 188 (BHCB); Serra da Bocaina, 6¹8'38'S, 4952'20'O, 24.VI.2015, fl., R.M. Harley et al. 57294 (MG). Parauapebas, Serra Norte, N1, 601'49”'S, 50¹7'27'O, 12.III.2009, fl., P.L. Viana et al. 3793 (BHCB); N4, 700-750 m, 14.III.1984, fl., A.S.L. da Silva et al. 1799 (MG).

Philodendron wullschlaegelii pode ser reconhecida pela lâmina foliar ovada de base cordada, espata não constrita e número de nervuras secundárias até 4 pares.
Espécie endêmica do Brasil com ocorrência nos estados de Maranhão, Pará, Goiás, Mato Grosso, Tocantins, Bahia, Ceará, e Minas Gerais. Na área do projeto é encontrada na Serra Sul: S11B e Serra da Bocaina; e Serra Norte: N1 e N4. Floração em março, abril, junho. Frutificação não observada.

\subsection{Philodendron sp.1}

Fig. 2h-i

Erva, epífita ou rupícola, ausência de seiva leitosa. Catafilo não observado, pecíolo intumescido 44,8 cm compr., genículo ausente, lâmina foliar não peltada, membranácea em material seco, ovada, não lobada, ápice obtuso-acuminado, base reflexacordada, ausência de perfurações, 46,6 × $34 \mathrm{~cm}$, nervura secundárias $>5$, nervura basal 1 , nervura coletora ausente. Inflorescência com pedúnculo $6,7 \mathrm{~cm}$ compr., espata levemente constrita na região mediana, lâmina persistente pós-antese, 15,7-17,8 cm comp., espádice com gineceu apresentando 4 lóculos, 1 óvulo por lóculo. Frutos não observados. Material selecionado: Parauapebas, S11-A, 6¹8'32'S, 50²7'15'O, 588 m, 16.III.2010, fr., A.J. Arruda et al. 1295 (BHCB).

Philodendron sp.1 pode ser reconhecida pelo pecíolo intumescido e nervuras secundárias em número maior que cinco.

Espécie conhecida somente do local de coleta na Serra Sul: S11A. Apesar de referida no rótulo da exsicata como Parauapebas, trata-se do município de Canaã dos Carajás. Frutificação em março. Floração não observada.

\subsection{Philodendron sp. 2}

Hemiepífita de caule aéreo, herbácea, ausência de seiva leitosa. Catafilo não observado, pecíolo $30,8 \mathrm{~cm}$ compr., genículo ausente, lâmina foliar não peltada, membranácea em material seco, ovada, não lobada, ápice não observado, base não observada, ausência de perfurações, medidas não observadas, nervuras secundárias 5 , nervura basal não observada, nervura coletora ausente. Inflorescência 2-6, com pedúnculo $6,1 \mathrm{~cm}$ compr., espata sem informação de cor, não constrita na região mediana, lâmina persistente pós-antese, $16,7 \mathrm{~cm}$ compr., espádice $15,8 \mathrm{~cm}$ compr. Frutos não observados.

Material selecionado: Serra dos Carajás, Salobo-2, 5'53'S, 50³0'O, 200 m, 11.VI.1982, fl., C.R. Sperling et al. 6088 (BHCB).

Philodendron sp. 2, pode ser reconhecida facilmente pela forma ovada da lâmina foliar, cinco pares de nervuras secundárias e espata não constrita, pode ser reconhecida facilmente. Semelhante a Philodendron wullschlaegelii, diferindo desta por 
apresentar mais de duas inflorescências (contra até duas) e margem ondulada das lâminas (contra inteira).

Espécie conhecida somente do local de coleta, na área da mina Salobo 2. Floração em junho. Frutificação não observada.

\section{Spathiphyllum Schott}

Espécies de Spathipyllum caracterizamse pelo hábito terrestre, rupícola ou raramente hemiepífita, bainha peciolar longa, lâmina foliar com nervuras secundárias paralelas e flores bissexuadas com perigônio. Habita a floresta tropical úmida e, raramente, floresta nebular. O gênero tem distribuição na América Tropical, Índias Ocidentais, Arquipélago Malaio e Melanesia, possui 49 espécies, sendo dez espécies no Brasil com duas endêmicas, e três para o estado do Pará (BFG 2015).

\section{Chave de identificação das espécies de Spathiphyllum das cangas da Serra dos Carajás}

1. Bainha foliar $<26 \mathrm{~cm}$ compr., nervuras secundárias 4-6 pares, espádice $<4 \mathrm{~cm}$ compr.

1'. Bainha foliar $>30 \mathrm{~cm}$ compr., nervuras secundárias $>6$ pares, espádice $>4 \mathrm{~cm}$ compr. 6.1. Spathiphyllum gardneri 6.2. Spathiphyllum humboldtii

6.1. Spathiphyllum gardneri Schott, Aroideae 1: 2. 1853.

Fig. $4 \mathrm{a}-\mathrm{c}$

Terrestre, caule não observado, ausência de seiva leitosa. Catafilos 4,1-8,3 cm compr., bainha 1,925,6 cm compr., pecíolo 11,8-47 cm compr., genículo presente, lâmina foliar não peltada, membranácea em material seco, elíptica, não lobada, ápice agudoreto, base agudo-cuneada, ausência de perfurações, 15,4-34,3 × 3-7,5 cm, nervuras secundárias 4-6 pares, nervuras basais ausentes, nervura coletora ausente. Inflorescência com pedúnculo $34-77,3 \mathrm{~cm}$ compr., espata não constrita, 6,2-10,8 × 2,2-3,6 $\mathrm{cm}$, espádice de flores bissexuadas, com perigônio, estipitado, 2,4-4 cm compr., estípite $0,8-1,9 \mathrm{~cm}$ compr. Infrutescência $3 \mathrm{~cm}$ compr.

Material selecionado: Canaã dos Carajás, S11-A, 6²0'55'S, 50²5'28'O, 603 m, 26.X.2010, fl., D.T. Souza et al. 1161 (BHCB); S11-D, 6023'30”S, 50¹9'5”O, $615 \mathrm{~m}$, 26.I.2012, fr., L.V.C. Silva et al. 1116 (BHCB).

Pode ser reconhecida pelo número de nervuras secundárias abaixo de 4 e bainha peciolar abaixo de $26 \mathrm{~cm}$ compr.

Espécie endêmica do Brasil com distribuição nos estados do Amazonas, Pará, Piauí, Ceará, Maranhão, Brasília, Goiás, Mato Grosso e Tocantins. Na Serra dos Carajás, é indicada para a Serra Sul: S11A e S11D. Floração em outubro e frutificação em janeiro.

6.2. Spathiphyllum humboldtii Schott, Aroid. 1: 2. 1853.

Terrestre, caule não observado, ausência de seiva leitosa. Catafilos não observados, bainha 30,2 cm compr., pecíolo 47,5 cm compr., genículo presente, lâmina foliar não peltada, membranácea em material seco, elíptica, não lobada, ápice agudo-acuminado, base agudo-cuneada, ausência de perfurações, $27,8 \times$ $8,6 \mathrm{~cm}$, nervuras secundárias $>6$ pares, nervuras basais ausentes, nervura coletora ausente. Inflorescência com pedúnculo $83,6 \mathrm{~cm}$ compr., espata não constrita, 9,6 cm compr., espádice de flores bissexuadas, com perigônio, estipitado, 4-11 cm compr., estípite $1 \mathrm{~cm}$ compr. Infrutescência não observada.

Material selecionado: Serra dos Carajás, Serra do Norte, lat: -6 long: -50.25 WGS84, C.C. Berg et al. 601 (MG).

Spathiphyllum humboldtii pode ser reconhecida pelo número de nervuras secundárias maior do $6 \mathrm{e}$ bainha peciolar acima de $30 \mathrm{~cm}$ compr.

Espécie distribuindo-se pelo Norte da América do Sul e Brasil, nos estados do Amazonas, Pará, Piauí, Ceará, Maranhão, Brasília, Goiás, Mato Grosso e Tocantins. Espécie indicada, para a Serra dos Carajás, na Serra do Norte, em platô não especificado.

\section{Syngonium Schott}

O gênero Syngonium é caracterizado pelo hábito epifítico, hemiepifítico e rastejante quando jovem, pecíolo com bainha longa, lâmina foliar pedatissecta, espata fortemente constrita e flores unissexuadas. Habita a floresta tropical úmida e áreas perturbadas. Possui distribuição na América Tropical e Índias Ocidentais, possui 34 espécies, sendo cinco no Brasil, e o estado do Pará possui duas espécies (BFG 2015).

7.1. Syngonium vellozianum Schott, Oesterr. Bot. Wochenbl. 4: 4181854.

Hemiepífita de caule aéreo herbáceo, presença de seiva leitosa. Catafilos e profilos não observados, bainha 10,2-26,9 cm compr., pecíolo 12,1-30,1 
cm compr., genículo ausente, lâmina foliar não peltada, membranácea em material seco, ovada, palmatipartida, ápice não observado, base lobada, ausência de perfurações, 15,4-24 $\times 18-23,9 \mathrm{~cm}$, nervuras secundárias 5 pares no folíolo mediano, nervuras basais ausentes, nervura coletora saindo acima da base foliar, 0,9$1,2 \mathrm{~cm}$ afastada da margem. Inflorescência com pedúnculo 4,7-9,5 cm compr., espata amarelada no tubo externamente com infrutescência madura, constrita na região mediana, lâmina caduca na frutificação, 5,5 cm compr., espádice de flores unissexuadas, sem perigônio. Frutos em sincarpo amarronzado quando maduro, 3,2-5,5 $\times 1,1-3,6 \mathrm{~cm}$.

Material selecionado: Canaã dos Carajás, S11-C, 6024'17'S, 50²3'59'O, 414 m, 28.I.2012, fr., L.V.C. Silva et al. 1149 (BHCB); S11-D, fl. e fr., I.M.C. Rodrigues et al. 593 (BHCB). Parauapebas, Igarapé baia, Área do POND, IX.2012, fr., L.C.B. Lobato \& L. Ferreira 4132 (MG). Parauapebas [Marabá], 31.I.1985, fr., O.C. Nascimento \& R.P. Bahia 1094 (MG).

Syngonium vellozianum pode ser reconhecida pela presença de seiva leitosa, lâmina palmatipartida e tubo da espata com coloração amarelada na infrutescência madura.

Espécie com distribuição ampla, encontrada na Bolívia e no Brasil, nos estados do Acre, Amazonas, Maranhão, Rondônia, Mato Grosso, Alagoas, Bahia, Ceará, Pernambuco, Espírito Santo, Minas Gerais, Rio de Janeiro, São Paulo e Paraná. Na área do projeto é encontrada na Serra Sul: S11C e S11D, em áreas de floresta como no Igarapé. Frutificação em janeiro e setembro. Floração não observada.

\section{Wolffia Horkel ex Schleid.}

Espécies de Wolffia possuem hábito aquático flutuante livre, frondes globosas, 1 flor por fronde, estame 1, estilete curto, estigma circular. O gênero distribui-se em todo o planeta, especialmente nas regiões tropicais e temperadas, e possui 11 espécies, sendo três no Brasil, e uma no estado do Pará (BFG 2015).

8.1. Wolffia brasiliensis Wedd., Ann. Sci. Nat., Bot. III, 12: 170. 1849.

Aquática flutuante, oblonga a elíptica, mais longa do que larga, achatada, esverdeada, pigmentos celulares epidérmicos acastanhados visíveis em plantas mortas, presença de pápula central cônica, 0,1-0,12 cm compr.; flores não observadas.
Material selecionado: Canaã dos Carajás, 6²8'17'S, 50²0'17'W, M.O. Pivari et al. 1734 (BHCB).

Wolffia brasiliensis pode ser reconhecida pelo hábito aquático, flutuante, tamanho diminuto, não ultrapassando $0,2 \mathrm{~cm}$ compr, com 1-2 frondes unidas e ausência de raiz.

Espécie com distribuição ampla, desde os Estados Unidos, passando pelo México, Américas Central e do Sul. No Brasil pode ser encontrada nos estados do Piauí, Ceará, Paraíba, Alagoas, Bahia, Mato Grosso, Mato Grosso do Sul e Paraná. Na área do projeto é encontrada em Canaã dos Carajás.

\section{Agradecimentos}

Agradeço ao Museu Paraense Emílio Goeldi e ao Instituto Tecnológico Vale, a estrutura e apoio. Aos curadores dos herbários BHCB, HCJS, IAN e MG, a disponibilização de material para a análise. Ao Dr. Pedro Viana e Dra. Ana Maria Giulietti, coordenadores do projeto "Flora de Carajás", o convite. Ao projeto objeto do convênio MPEG/ITV/ FADESP (01205.000250/2014-10) e ao projeto aprovado pelo CNPq (processo 455505/2014-4), o financiamento. Ao ICMBio, especialmente ao Frederico Drumond Martins, a licença de coleta concedida e suporte nos trabalhos de campo. Ao Alex Araújo, a confecção das ilustrações e a Nara Mota e Pedro Viana, as fotos enviadas.

\section{Referências}

BFG - The Brazil Flora Group (2015) Growing knowledge: an overview of seed plant diversity in Brazil. Rodriguésia 66: 1085-1113.

Boyce PC \& Croat TB [2011 onwards] The Überlist of Araceae, totals for published and estimated number of species in aroid genera. Disponível em <http:// www.aroid.org/genera/160330uberlist.pdf $>$.

Coelho MAN, Waechter JL \& Mayo SJ (2009) Revisão taxonômica das espécies de Anthurium (Araceae) seção Urospadix subseção Flavescentiviridia. Rodriguesia 60: 799-864.

Coelho MAN, Gonçalves EG, Sakuragui CM \& Temponi LG (2012) Araceae. In: Wanderley MGL, Shepherd GJ, Melhem TS, Giulietti AM \& Martins SE (eds.) Flora Fanerogâmica do estado de São Paulo. Instituto de Botânica, São Paulo. Vol. 7, pp. 27-71.

Croat TB (1983) A revision of the genus Anthurium (Araceae) of Mexico and Central America. Part I: Mexico and Middle America. Annals of the Missouri Botanical Garden 70: 211-420. 
Croat TB (1991) A revision of Anthurium section Pachyneurium (Araceae). Annals of the Missouri Botanical Garden 78: 539-855.

Croat TB (2004) Revision of Dieffenbachia (Araceae) of Mexico, Central America and the West Indies. Annals of the Missouri Botanical Garden 91: 594-668.
Madison M (1978) The species of Anthurium with palmately divided leaves. Selbyana 2: 239-282.

Mayo SJ, Bogner J \& Boyce PC (1997) The genera of Araceae. Royal Botanic Gardens, Kew. 370p.

Soares ML, Mayo SJ \& Gribel R (2013) A preliminar taxonomic revision of Heteropsis (Araceae). Systematic Botany 38: 925-974.

\section{Lista de exsicatas}

Almeida TE 2168 (1.5), 2411 (1.2), 2476 (2.2), 2510 (5.1). Arruda AJ 504 (6.1), 731 (1.3), 1220 (5.1), 1240 (5.2), 1268 (5.2), 1295 (5.7), 1299 (5.1), 1300 (5.1), 1306 (5.1), 1407 (5.1), 1446 (5.1). Berg CC 601 (6.2). Cardoso A 1959 (5.5). Carreira LMM 3391 (5.6). Cavalcante P 2181 (5.5), 2631 (1.4). Chaves PP 4 (1.4). Daly DC 1697 (1.1.), 1849 (1.2), 1856 (5.3). Giacomin LL 1185 (3.1). Giorni VT 188 (5.6), 305 (1.2), 331 (1.5), 341 (1.1). Gontijo FD 145 (6.1), 156 (5.6), 157 (6.1), 158 (4.1), 58 (1.2). Harley RM 57294 (5.6), 57387 (1.6), 57436 (1.4). Lima MPM 117 (1.4), 132 (5.7). Lobato LCB 3891 (1.4), 3904 (1.4), 4113 (3.1), 4127 (1.2), 4132 (7.1), 4163 (3.1), 4166 (2.1), 4196 (3.1), 4259 (5.2), 4332 (1.4). Mota NFO 1080 (1.1), 1080 (1.4), 3404 (1.4). Nascimento OC 1094 (7.1), 1114 (5.3), 952 (1.4). Pivari MO 1734 (8.1). Rocha AES 1830 (1.4). Rodrigues ICM 530 (5.1), 532 (5.1), 533 (5.1), 601 (5.1), 564 (5.4). Rosa NA 5042 (5.7), 5043 (1.4). Santos RS 124 (1.4), 15 (1.4), 178 (5.7). Secco R. 136 (1.4). Silva ASL 1799 (5.6), 1866 (1.4). Silva LVC 1116 (6.1), 1149 (7.1), 1165 (1.5), 1201 (5.1), 1266 (3.1), 1281 (4.1), 1282 (5.2), 1284 (1.5), 1317 (5.1). Souza DT 1161 (6.1), 1184 (5.1). Sperling CR 5965 (3.1), 6002 (5.2), 6088 (5.8), 6196 (4.2). Torres RB 18438 (3.1). Viana PL 3793 (5.6), 5593 (5.7), 6211 (1.6). Vidal CV 645 (3.1). 